\title{
ВИКОРИСТАННЯ ФАРМАКОФОРНОГО МОДЕЛЮВАННЯ ДЛЯ ЦІЛЕСПРЯМОВАНОГО ПОШУКУ ПОТЕНЦІЙНИХ ГІПОТЕНЗИВНИХ ЗАСОБІВ РЯДУ ПОХІДНИХ П’ЯТИЧЛЕННИХ ГЕТЕРОЦИКЛІВ
}

Вступ. Фармакофорне моделювання - один з найбільш ефективних методів віртуального скринінгу. Цей метод дає можливість встановити набір та взаємне розташування специфрічних молекулярних оррагментів, які необхідні для прояву певної біологічної активності. Підвищений артеріальний тиск $є$ основною причиною розвитку серцевих, судинних і церебральних ускладнень, а саме ішемічноїхвороби серця, хронічної серцевої недостатності, порушень мозкового кровообігу. Цілеспрямований пошук гіпотензивних агентів із застосуванням новітніх методів, зокрема фрармакофрорного моделювання, серед похідних п'ятичленних гетероциклів є доцільним і актуальним.

Мета дослідження-провести фрармакофрорне моделювання ряду похідних п'ятичленних гетероциклів (1,3-тіазолу, 1,3,4-тіадіазолу та 1,3,4-тріазолу) для цілеспрямованого пошуку потенційних гіпотензивних засобів.

Методи дослідження. Об'єктами дослідження були синтезовані похідні 1,3-тіазолу, 1,3,4-тіадіазолу та 1,3,4-тріазолу зі встановленою гіпотензивною активністю. Фармакофрорне моделювання проводили у спеціалізованій програмі для молекулярного моделювання хемоінформатики Molecular Operating Environment.

Результати й обговорення. У процесі пошуку ймовірного фрармакофрора розроблено фрармакофорні моделі, які характеризуються різним складом та координатами фрармакофорних центрів, а також точністю класифікації. Для виявлення та скринінгу гіпотензивної дії вибрано чотирикомпонентні фрармакоорорні моделі з точністю класифрікації 0,52-0,61 і ступенем перекриття активних сполук 1,76-2,78. Фармакофрорна модель із найвищою точністю та ступенем перекриття структурно складається з ароматичного кільця, двох гідрофробних областей та проекції акцептора водневого зв'язку з характерним взаємним просторовим розташуванням. Під час дослідження узгодженості активних речовин із фрармакофрорною моделлю було виявлено потенційну взаємодію тетразолового кільця валсартану з біомішенню в якості акцептора водневого зв'язку та через механізм ароматичної взаємодії. Проведено узгодження структур молекул віртуальної бази з фрармакофорною моделлю.

Висновки. Проведене фрармакофрорне моделювання ряду похідних п'ятичленних гетероциклів - 1,3-тіазолу, 1,3,4-тіадіазолу та 1,3,4-тріазолу зі встановленою гіпотензивною активністю дозволило виділити можливий фрармакофор, що складається з ароматичного кільця, двох гідрофробних областей та проекції акцептора водневого зв'язку. Точність класифрікації активних та неактивних сполук даної моделі становить 0,61. Одержану фрармакофрорну модель можна використовувати для віртуального скринінгу і цілеспрямованого пошуку нових гіпотензивних засобів.

КЛЮЧОВІ СЛОВА: фрармакофорне моделювання; похідні п'ятичленних гетероциклів - 1,3-тіазолу, 1,3,4-тіадіазолу, 1,3,4-тріазолу; гіпотензивна активність.

ВСТУП. Фармакофорне моделювання-один 3 найбільш ефективних методів віртуального скринінгу. Цей метод дає можливість встановити набір та взаємне розташування специфрічних молекулярних сррагментів, які необхідні для прояву певної біологічної активності $[1,2]$.

Підвищений артеріальний тиск $\epsilon$ основною причиною розвитку серцевих, судинних і церебральних ускладнень, а саме ішемічної хвороби серця, хронічної серцевої недостатності, порушень мозкового кровообігу $[3,4]$. Недостатня (c) І. В. Драпак, 2019. ефективність та низка побічних реакцій гіпотензивних лікарських засобів обґрунтовують надзвичайну актуальність пошуку нових синтетичних гіпотензивних засобів [5]. Згідно з літературними даними та результатами попередніх досліджень, встановлено антиоксидантну, кардіопротекторну, діуретичну, гіпотензивну дію похідних п'ятичленних гетероциклів-1,3-тіазолу, 1,3,4-тіадіазолу, 1,3,4-тріазолу [6-9]. Цілеспрямований пошук гіпотензивних агентів із застосуванням новітніх методів, зокрема фрармакофорного моделювання, серед похідних 1,3-тіазолу, 
1,3,4-тіадіазолу та 1,3,4-тріазолу є доцільним і актуальним.

Мета дослідження - провести фрармакофрорне моделювання ряду похідних п'ятичленних гетероциклів (1,3-тіазолу, 1,2,4-тіадіазолу та 1,3,4-тріазолу) для цілеспрямованого пошуку потенційних гіпотензивних засобів.

МЕТОДИ ДОСЛІДЖЕННЯ. Об'єктамИ Дослідження (рис. 1) були синтезовані похідні 1,3-тіазолу, 1,3,4-тіадіазолу та 1,3,4-тріазолу зі встановленою гіпотензивною активністю та сполуки 3 віртуальної бібліотеки [10-13]. Гіпотензивну активність вивчали в дослідах in vivo на лабораторних білих щурах в Інституті фрармакології та токсикології НАМН України під керівництвом проф. Н. М. Серединської. Вплив досліджуваних сполук та препаратів порівняння - амлодипіну і валсартану на серцево-судинну систему визначали за показниками артеріального тиску в хвостовій артерії тварин [14].

Фармакофорне моделювання проводили у спеціалізованій програмі для молекулярного моделювання хемоінформатики Molecular Operating Environment (MOE) версії 2007.09 [15] Після завантаження бази структур до програми оптимізовано геометрію молекулярних структур методом молекуляної механіки з використанням силового поля MMFF94x. Шляхом стохастичного пошуку згенеровано базу конорормерів для кожної з досліджуваних структур, для кожного конорормера генерували координати наявних потенційних фрармакофорних центрів відповідно до їх видів: донорів та акцепторів водневих зв'язків, гідрофообних областей, ароматичних циклів тощо. Здійснювали поетапний автоматичний пошук фармакофорних моделей, що полягав у побудові всіх комбінацій потенційних фрармакофрорних центрів, які $є$ спільними для всіх активних сполук, та наступному вдосконаленні даних комбінацій послідовним підбором і додаванням третього, четвертого і п'ятого фрармакосорних центрів за умови, що внесення нового срармакофрорного центру покращує точність класифрікації сполук на активні та неактивні розробленою фрармакофорною моделлю. Крім точності моделі, аналізували також такий параметр, як ступінь взаємного перекриття активних сполук. Чим вищі значення цих показників, тим більший просторовий збіг консрормацій активних сполук, що є необхідною передумовою для того, щоб зв'язування досліджуваних активних сполук з біомішенню проходило спільним для них способом.

РЕЗУЛЬТАТИ Й ОБГОВОРЕННЯ. У процеСі пошуку ймовірного фрармакофора розроблено фрармакофорні моделі, які характеризуються різним складом та координатами фрармакофорних центрів, а також точністю класифрікації. Для виявлення та скринінгу гіпотензивної дії вибрано фрармакофорні моделі з точністю класифрікації 0,52-0,61 і ступенем перекриття 1,76-2,78 (табл.). Усі знайдені фрармакофорні моделі були чотирикомпонентними. Додавання п'ятої фрармакофорної анотації до цих моделей не покращувало їх прогностичного потенціалу. Фармакофрорна модель 1 характеризувалася найвищим ступенем взаємного перекриття активних сполук 2,78, точність моделі становила 0,61.<smiles>[R]c1s/c(=N/[Al])n([R])c1[R]</smiles>

$\mathbf{R}^{1}=\mathrm{Me}, \mathrm{Ar} ; \mathbf{R}^{2}=\mathrm{H}, \mathrm{Ac}$ $\mathbf{R}=\mathrm{N}$-morpholinyl, Alk 3-morpholinyl-alkyl, allyl, $\mathrm{H}$<smiles>[R]Nc1nnc([R])s1</smiles>

$\mathbf{R}^{1}=$ Ar, Alk, S-alkyl $\mathbf{R}^{2}=$ Ar, Alk<smiles>[R]Cn1nc([R1])n([R2])c1=S</smiles>

$\mathbf{R}=\mathrm{N}$-morpholinyl, $\mathrm{N}$-piperidinyl; $\mathbf{R}^{\mathbf{1}}=\mathrm{Ar} ; \mathbf{R}^{\mathbf{2}}=\mathrm{Ar}$

Рис. 1. Структура досліджуваних сполук.

Таблиця - Характеристики розроблених фармакофорних моделей для виявлення та скринінгу гіпотензивної дії

\begin{tabular}{|c|c|l|c|c|}
\hline $\begin{array}{c}\text { № } \\
\text { моделі }\end{array}$ & $\begin{array}{c}\text { Кількість } \\
\text { фармакофрор- } \\
\text { них центрів }\end{array}$ & \multicolumn{1}{|c|}{ Перелік фрармакофорних центрів } & $\begin{array}{c}\text { Ступінь взаємного } \\
\text { перекриття активних } \\
\text { сполук }\end{array}$ & $\begin{array}{c}\text { Точність } \\
\text { класифрі- } \\
\text { кації }\end{array}$ \\
\hline 1 & 4 & $\begin{array}{l}\text { Ароматичне кільце, дві гідрофобні області, } \\
\text { проекція акцептора водневого зв'язку }\end{array}$ & 2,78 & 0,61 \\
\hline 2 & 4 & $\begin{array}{l}\text { Ароматичне кільце, гідрофобна область і дві } \\
\text { проекції акцепторів водневого зв'язку }\end{array}$ & 2,12 & 0,52 \\
\hline 3 & 4 & $\begin{array}{l}\text { Дві гідрофобні області й дві проекції акцепто- } \\
\text { рів водневого зв'язку }\end{array}$ & 1,76 & 0,52 \\
\hline
\end{tabular}


Структурно фрармакофрорна модель 1 складається 3 ароматичного кільця, двох гідросробних областей та проекції акцептора водневого зв'язку з характерним взаємним просторовим розташуванням (рис. 2). Під проекцією акцептора водневого зв'язку мають на увазі область 3 підвищеною електронною густиною (поблизу потенційних донорів електронної пари), при потраплянні в яку атомів Гідрогену біомішені 3 достатнім додатнім парціальним зарядом утвориться водневий зв'язок.

Під час дослідження узгодженості активних речовин із фрармакофорною моделлю було виявлено потенційну взаємодію тетразолового кільця валсартану з біомішенню (рис. 3) в якості акцептора водневого зв'язку та через механізм ароматичної взаємодії (стекінг або п-п взаємодія). Це добре узгоджується з літературними даними [16], за якими основна взаємодія валсартану 3 рецептором ангіотензину II 1 типу реалізується через водневий зв'язок Arg167 3 Нітрогеном тетразолового кільця та через ароматичну взаємодію цього ж тетразолового фррагмента 3 ароматичним кільцем френілаланіну Phe182.

Проведено узгодження 3 фрармакофрорною моделлю бази віртуальних сполук. Так, у сполуці 1-[(2-[(4-метоксисеніл)іміно]-4-метил-3-(4-метилпіперазин-1-іл)-2,3-дигідро-1,3-тіазол-5-іл] етан-1-он гідрохлориді (узгодження з фрармакосрорною моделлю RMSD=0,723Å) роль ароматичного ядра фрармакофора відіграє френільне кільце, з'єднане з 2-м положенням тіазолу через іміно-лінкер, а роль акцептора водневого зв'язку - Оксиген метоксильної групи в пара-положенні цього френільного кільця (рис. 4).

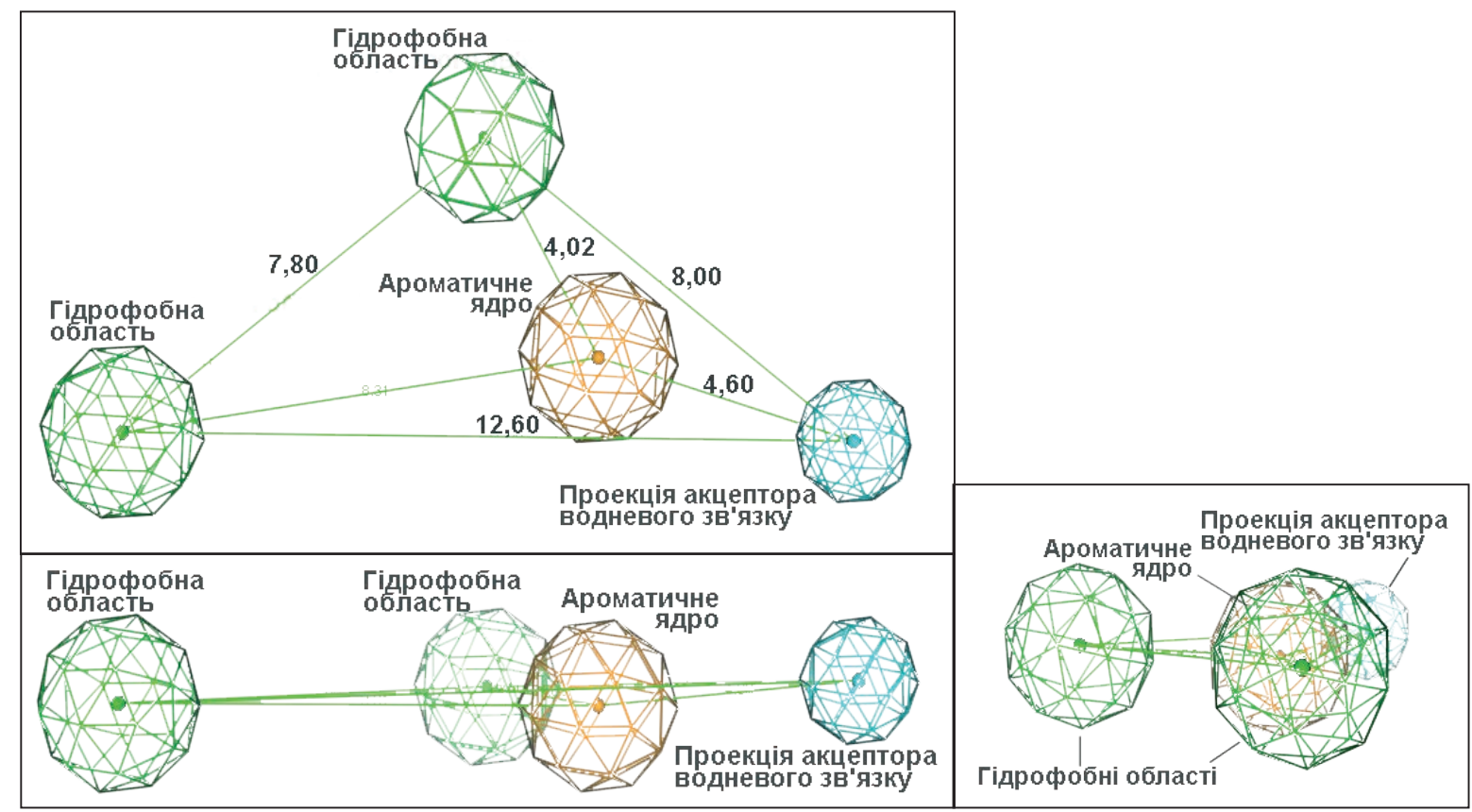

Рис. 2. Схема фрармакофорної моделі 1 у трьох проекціях. Числами позначено відстань між фрармакофрорними центрами в А.

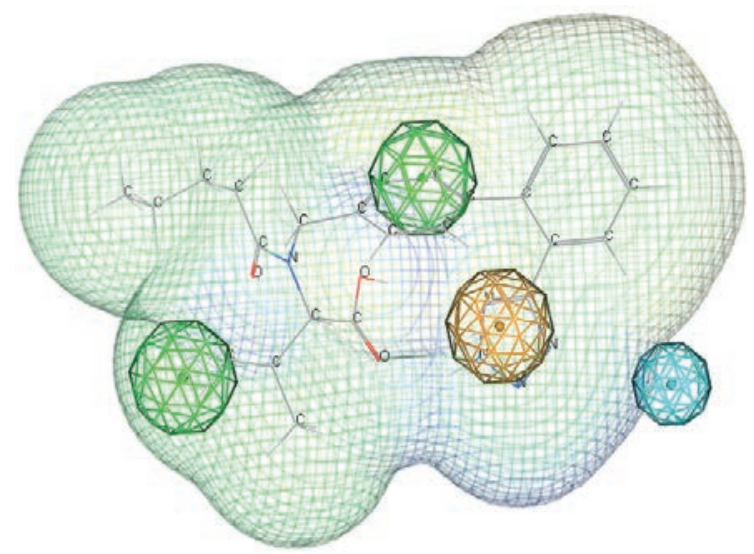

Рис. 3. Молекула валсартану в узгодженій з фармакофорною моделлю конформації. 
Структура [3-алліл-4-(41-метоксифеніл)-3Нтіазол-2-іліден]-(3²-трифрлуоро-метил-феніл) аміну гідроброміду узгоджується з рармакофорною моделлю ще більшою мірою з показником RMSD $=0,571 \AA$. При цьому, аналогічно сполуці 1-[(2-[(4-метоксифеніл)іміно]-4-метил-3-(4-метилпіперазин-1-іл)-2,3-дигідро-1,3-тіазол-5-іл] етан-1-он гідрохлориду, за ароматичну взаємодію відповідає френільне ядро, однак у такому разі приєднане до 4-го положення тіазолу. Слід зазначити, що ядро розміщене точно по центру відповідної фрармакофорної анотації, а роль акцептора водневого зв'язку відіграє Оксиген метоксильної групи в пара-положенні цього френільного ядра. Гідрофобні області фрармакофорної моделі збігаються з розташуванням іншого френільного кільця (приєднаного до 2-го положення тіазолу через іміно-лінкер) та положенням Карбону N-алільної групи (рис. 5).

ВИСНОВКИ. Проведене фрармакофорне моделювання ряду похідних п'ятичленних гетероциклів - 1,3-тіазолу, 1,3,4-тіадіазолу та 1,3,4-тріазолу зі встановленою гіпотензивною активністю дозволило виділити можливий фармакофрор, що складається з ароматичного кільця, двох гідрофобних областей та проекції акцептора водневого зв'язку. Точність класифрікації активних та неактивних сполук даної моделі становить 0,61. Одержану фрармакофрорну модель можна використовувати для віртуального скринінгу і цілеспрямованого пошуку нових гіпотензивних засобів.

\section{СПИСОК ЛІТЕРАТУРИ}

1. Computational approaches in target identification and drug discovery / T. Katsila, G. A. Spyroulias, G. P. Patrinos, M. T. Matsoukas // Computational and Structural Biotechnology Journal. - 2016. - 14. - P. 177184.

2. Yang S.Y. Pharmacophore modeling and applications in drug discovery: challenges and recent advances / S. Y. Yang // Drug Discovery Today. - 2010. 15, Issues 11-12. - P. 444-450.

3. Drozdz D. Cardiovascular changes during chronic hypertensive states / D. Drozdz, K. Kawecka-Jaszcz // Pediatr. Nephrol. - 2014. - 29 (9). - P. 1507-1516.

4. Selected major risk factors and global and regional burden of disease / M. Ezzati, A. D. Lopez, A. Rodgers [et al.] // Lancet. - 2002. - 360 (9343). - P. 1347-1360.

5. Discontinuation of antihypertensive drugs due to adverse events. a systematic review and meta-analysis / S. D. Ross, K. S. Akhras, S. Zhahg, M. Rozinsky // Pharmacotherapy. - 2001. - 21 (8). - P. 940-953.

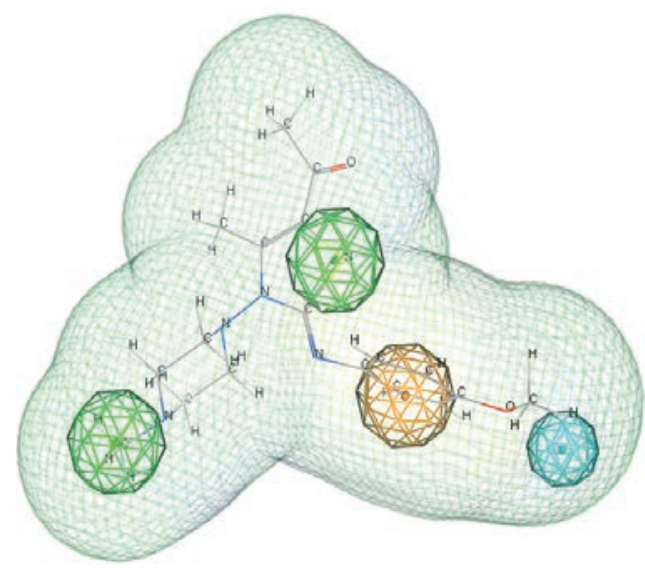

Рис. 4. Сполука 1-[(2-[(4-метоксифеніл)іміно]-4-метил3-(4-метилпіперазин-1-іл)-2,3-дигідро-1,3-тіазол-5-іл] етан1-он гідрохлорид в узгодженій з фрармакофорною моделлю конфрормації.

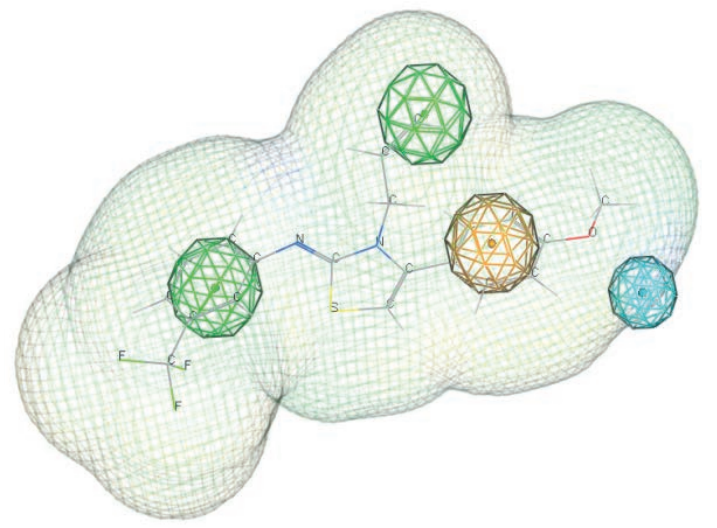

Рис. 5. Сполука [3-алліл-4-(41-метоксисреніл)-3Н-тіазол2-іліден]-(3²-трифрлуоро-метил-феніл) аміну гідробромід в узгодженій з фармакофорною моделлю консрормації. 
10. Пат. на корисну модель u201900319. Гідрохлорид 1-\{3-[2-(3,4-диметокси-феніл)-етил]-4-метил-1-2-среніліміно-2,3-дигідро-тіазол-5-іл\}-етанону, що проявляє гіпотензивну дію / Драпак І. В., Зіменковський Б. С., Серединська Н. М., Демченко А. М. ; заявник і патентовласник Львів. нац. мед. ун-т імені Данила Галицького. - № 135563 ; заявл. 11.01.19 ; опубл. 10.07.19, Бюл. № 13.

11. Search for biologically active substances with antimicrobial and antifungal action in the series of 2.5-disubstituted 1, 3, 4-tiadiazoles / I. V. Sych, I. V. Drapak, M. M. Suleiman [et al.] // Research Journal of Pharmacy and Technology. - 2019. - Vol. 12 (6). - P. 1-6.

12. Perekhoda L. O. The synthesis and physicochemical properties of new derivatives of 5-R-phenylamino-2-mercapto-1,3,4-tiadiazole / L. O. Perekhoda, N. P. Kobzar, I. V. Drapak // News of Pharmacy. - 2016. 1 (85). - P. 24-28.

13. Aminomethylation of 1,2,4-triazole-3-thiones containing piperidine moiety in order to synthesine new biologically active compounds / [H. O. Yeromina, I. V. Drapak, Z. G. leromina et al.] // Сучасна фрармація: історія, реалії та перспективи розвитку : матеріали наук.-практ. конор. $з$ міжнар. участю, присвяченої 20-й річниці заснування Дня фрармацевтичного працівника України (м. Харків, 19-20 верес. 2019 р.) : у 2 т. / [редкол. : А. А. Котвіцька та ін.]. - Харків : НФаУ, 2019. - Т. 1. C. $45-46$.

14. Доклінічні дослідження лікарських засобів : метод. рек. / за ред. О. В. Стефранова. - К. : Авіцена, 2001. -528 c.

15. Chemical Computing Group Inc. MOE 2007.09 (Molecular OperatingEnvironment software). URL : http:// www.chemcomp.com.

16. Leveraging NMR and X-ray data of the free ligands to build better drugs targeting angiotensin II type 1 G-protein coupled receptor / T. F. Kellici, D. Ntountaniotis, E. Kritsi [et al.] // Current Medicinal Chemistry. 2016. - 23. - Issue 1. - P. 36-59.

\section{REFERENCES}

1. Katsila, T., Spyroulias, G.A., Patrinos, G.P., \& Matsoukas, M.T. Computational approaches in target identification and drug discovery (2016). Minos-Timotheos Matsoukas a Computational and Structural Biotechnology Journal, 14, 177-184. doi: 10.1016/j.csbj.2016.04.004.

2. Yang S.Y. (2010). Pharmacophore modeling and applications in drug discovery: challenges and recent advances. Drug Discovery Today, 15 (11-12), 444-450. https://doi.org/10.1016/j.drudis.2010.03.013

3. Drozdz, D., \& Kawecka-Jaszcz, K. (2014). Cardiovascular changes during chronic hypertensive states. Pediatr. Nephrol., 29 (9), 1507-1516. doi: 10.1007/ s00467-013-2614-5.

4. Ezzati, M., Lopez, A.D., Rodgers, A., Vander Hoorn, S., \& Murray, C.J. (2002). Comparative Risk Assessment Collaborating Group. Selected major risk factors and global and regional burden of disease. Lancet, 360 (9343), 1347-1360. doi: 10.1016/S01406736(02)11403-6.

5. Ross, S.D., Akhras, K.S., Zhahg, S., \& Rozinsky, M. (2001). Discontinuation of antihypertensive drugs due to adverse events. a systematic review and meta-analysis. Pharmacotherapy, 21 (8), 940-953. doi: 10.1592/ phco.21.11.940.34520

6. Drapak, I.V. (2019). In silico scryninh likopodidnyh molekul dlia likuvannia sertsevo-sudynnykh zakhvoriuvan na osnovi pryvileiovanykh piatychlennykh heterotsytiv [In silico screening of drug-like molecules for the treatment of cardiovascular diseases on the basis of five-membered privileged heterocycles]. Farmatsevtychnyi zhurnal Pharmaceutical Journal, 4, 61-72 [in Ukrainian].

7. Perekhoda, L., Yeromina, H., Drapak, I., Kobzar, N., Smolskiy, O., \& Demchenko, N. (2017). The antioxidant properties of 1-[2-(R-phenylimino)-4-methyl-3-(3-[morpholine-4yl]propyl)-2,3-dihydro-1,3-thiazol-5-yl]ethane1-one derivatives under conditions of artificial oxidative stress in vitro. Saudi Journal of Medical and Pharmaceutical Sciences, 3 (1), 55-59.
8. Drapak, I., Perekhoda, L., Demchenko, N., Suleiman, M., Rakhimova, M., Demchuk, I., ..., \& Gerashchenko, I. (2019). Cardioprotective Activity of Some 2-Arylimino-1, 3-Thiazole Derivatives. Scientia Pharmaceutica, 87, 7, 8. doi:10.3390/scipharm87010007

9. Drapak, I.V. (2019). Syntes, doslidzhennia diuretychnoi aktyvnosti ta QSAR-analiz N-(1,3,4-thiadiazol2-yl)zamishchenyh amidiv kyslot alkankarbonovoho riadu [Synthesis, diuretic activity research and QSARanalysis of N-(1,3,4-tiadiazol-2-il)substituted amides of alkanecarboxylic acids]. Farmatsevtychnyi zhurnal Pharmaceutical Journal, 2, 55-65 [in Ukrainian].

10. Drapak, I.V., Zimenkovskyi, B.S., Seredinska, N.M., \& Demchenko, A.M. (2019). Patent na korysnu model № 135563 u201900319 hidrohloryd 1-\{3-[2-(3,4-dymetoxyphenil)-etyl]-4-metyl-1-2-phenilimino-2,3-dyhidro-thiazol5-yl\}-etanonu, shcho proiavliaie hipotenzyvnu diiu [Utility model patent u201900319 1-\{3-[2-(3,4-Dimethoxyphenyl)-ethyl]-4-methyl-1-2-phenylimino-2,3-dihydrothiazol-5-yl\}-ethanone hydrochloride, which is hypotensive action]. Applicant and patentee of Danylo Halytskyi Lviv National Medical University. Claimed 01/11/19; publ. 07/10/19. Bul. No. 13. [in Ukrainian].

11. Sych, I.V., Drapak, I.V., Suleiman, M.M., Rakhimova, M.V., Kobzar, N.P., Sych, I.A., \& Perekhoda, L.O. (2019). Search for biologically active substances with antimicrobial and antifungal action in the series of 2.5-disubstituted 1, 3, 4-tiadiazoles. Research Journal of Pharmacy and Technology, 12 (6), 1-6.

12. Perekhoda, L.O., Kobzar, N.P., \& Drapak, I.V. (2016). The synthesis and physicochemical properties of new derivatives of 5-R-phenylamino-2-mercapto-1,3,4-tiadiazole. News of Pharmacy, 1 (85), 24-28.

13. Yeromina, H.O., Drapak, I.V., leromina, Z.H., Perekhoda, L.O., \& Heorhiiants, V.A. (2019). Aminomethylation of 1,2,4-triazole-3-thiones containing piperidine moiety in order to synthesine new biologically active compounds. Proceedings of the scientific-practical confer- 
ence with international participation, dedicated to the 20th anniversary of the founding of the Day of the Pharmaceutical Worker of Ukraine: Suchasna farmatsiia: istoriia, realii ta perspektyvy rozvytku (19-20 ver 2019) Modern Pharmacy: History, Realities and Prospects of Development (19-20 Sept 2019). Kharkiv [in Ukrainian]

14. Stefanova, O.V. (Ed.). (2001). Doklinichni doslidzhennia likarskykh zasobiv (metodychni rekomendatsii) [Preclinical drug research: a method. recom.]. Kyiv: Avitsena [in Ukrainian].
15. Chemical Computing Group Inc. MOE 2007.09 (Molecular OperatingEnvironment software). Retrieved from: http://www.chemcomp.com.

16. Kellici, T.F., Ntountaniotis, D., Kritsi, E., Zervou, M., Zoumpoulakis, P., Potamitis, C., ..., \& Mavromoustakos, T. (2016). Leveraging NMR and X-ray data of the free ligands to build better drugs targeting angiotensin II type $1 \mathrm{G}$-protein coupled receptor. Current Medicinal Chemistry, 23, 1, 36-59.

ЛЬВОВСКИЙ НАЦИОНАЛЬНИЙ МЕДИЦИНСКИЙ УНИВЕРСИТЕТ ИМЕНИ ДАНИЛА ГАЛИЦКОГО

\section{ИСПОЛЬЗОВАНИЕ ФАРМАКОФОРНОГО МОДЕЛИРОВАНИЯ ДЛЯ ЦЕЛЕНАПРАВЛЕННОГО ПОИСКА ПОТЕНЦИАЛЬНЫХ ГИПОТЕНЗИВНЫХ СРЕДСТВ РЯДА ПРОИЗВОДНЫХ ПЯТИЧЛЕННЫХ ГЕТЕРОЦИКЛОВ}

\section{Резюме}

Вступление. Фармакофрорное моделирование - один из наиболее эфрфективных методов виртуального скрининга. Этот метод дает возможность установить набор и взаимное расположение специорических молекулярных фррагментов, которые необходимы для проявления определенной биологической активности. Повышенное артериальное давление является основной причиной развития сердечно-сосудистых и церебральных осложнений, а именно ишемической болезни сердца, хронической сердечной недостаточности, нарушений мозгового кровообращения. Целенаправленный поиск гипотензивных агентов с применением новейших методов, в частности фрармакофрорного моделирования, среди производных пятичленных гетероциклов целесообразно и актуально.

Цель исследования - провести фрармакофрорное моделирование ряда производных пятичленных гетероциклов (1,3-тиазола, 1,3,4-тиадиазола и 1,3,4-триазола) для целенаправленного поиска потенциальных гипотензивных средств.

Методы исследования. Объектами исследования были синтезированные производные 1,3-тиазола, 1,3,4-тиадиазола и 1,3,4-триазола с установленной гипотензивной активностью. Фармакофорное моделирование проводили в специализированной программе для молекулярного моделирования хемоинорорматики Molecular Operating Environment.

Результаты и обсуждение. В процессе поиска возможного фрармакофора разработаны фрармакофорные модели, характеризующиеся различным составом и координатами фрармакофорных центров, а также точностью классифрикации. Для выявления и скрининга гипотензивного действия выбрано четырекомпонентные фрармакофрорные модели с точностью классифрикации 0,52-0,61 и степенью перекрытия активных соединений 1,76-2,78. Фармакофрорная модель с самой высокой точностью и степенью перекрытия структурно состоит из ароматического кольца, двух гидрофробных областей и проекции акцептора водородной связи с характерным взаимным пространственным расположением. Во время исследования согласованности активных веществ с фрармакофорной моделью было выявлено потенциальное взаимодействие тетразолового кольца валсартана с биомишенью в качестве акцептора водородной связи и через механизм ароматического взаимодействия. Проведено согласование структур молекул виртуальной базы с фрармакофорной моделью.

Выводы. Проведенное фрармакофрорное моделирование ряда производных пятичленных гетероциклов - 1,3-тиазола, 1,3,4-тиадиазола и 1,3,4-триазола с установленной гипотензивной активностью позволило выделить возможный фрармакофрор, состоящий из ароматического кольца, двух гидрофробных областей и проекции акцептора водородной связи. Точность классификации активных и неактивных соединений данной модели составляет 0,61. Полученную фрармакофорную модель можно использовать для виртуального скрининга и целенаправленного поиска новых гипотензивных средств.

КЛЮЧЕВЫЕ СЛОВА: фрармакофорное моделирование; производные пятичленых гетероциклов 1,3-тиазола, 1,3,4-тиадиазола, 1,3,4-триазола; гипотензивная активность. 


\section{THE USE OF PHARMACOPHORE MODELING FOR A PURPOSEFUL SEARCH OF POTENTIAL ANTIHYPERTENSIVE AGENTS OF A NUMBER OF DERIVATIVES OF FIVE-MEMBERED HETEROCYCLES}

\section{Summary}

Introduction. Pharmacophore modeling is one of the most effective virtual screening methods. This method allows to determine the set and relative arrangement of specific molecular fragments that are required for the manifestation of a particular biological activity. Increased blood pressure is a major cause of cardiac, vascular, and cerebral complications, including ischemic heart disease, chronic heart failure, and circulatory disorders. Purposeful search for antihypertensive agents using the latest methods, including pharmacophore modeling, among derivatives of five-membered heterocycles is appropriate and relevant. Pharmacophore modeling is one of the most effective virtual screening methods. This method allows to determine the set and relative arrangement of specific molecular fragments that are required for the manifestation of a particular biological activity. Increased blood pressure is a major cause of cardiac, vascular, and cerebral complications, including ischemic heart disease, chronic heart failure, and circulatory disorders. Purposeful search for antihypertensive agents using the latest methods, including pharmacophore modeling, among derivatives of five-membered heterocycles is appropriate and relevant.

The aim of the study - the pharmacophore modeling of a series of five-membered heterocycle derivatives, 1,3-thiazole, 1,3,4-thiadiazole, and 1,3,4-triazole, for the purposeful search for potential antihypertensive agents.

Research Methods. 1,3-thiazole, 1,3,4-thiadiazole and 1,3,4-triazole derivatives with established antihypertensive activity were synthesized as objects of study. Pharmacophore modeling was performed in a specialized program for molecular modeling of chemoinformatics Molecular Operating Environment.

Results and Discussion. In the process of searching for a probable pharmacophore, pharmacophore models have been developed that are characterized by different composition and coordinates of pharmacophore centers, as well as classification accuracy. For the detection and screening of antihypertensive effects, four-component pharmacophore models were selected with a classification accuracy of 0.52-0.61 and an overlap of active compounds of 1.76-2.78. Pharmacophore model with the highest accuracy and degree of overlap structurally consists of an aromatic ring, two hydrophobic regions and a projection of a hydrogen bond acceptor with a characteristic mutual spatial arrangement and through the aromatic interaction mechanism. The structures of the virtual base molecule structures were harmonized with the pharmacophore model.

Conclusions. Conducted pharmacophore modeling of a number of derivatives of five-membered heterocycles 1,3-thiazole, 1,3,4-thiadiazole and 1,3,4-triazole with established antihypertensive activity made it possible to distinguish a possible pharmacophore consisting of an aromatic ring, two Hydrophobic Areas and Projections of the Hydrogen Bond Acceptor. The accuracy of the classification of active and inactive compounds in this model is 0.61 . The resulting pharmacophore model can be used for virtual screening and targeted search for new antihypertensive agents.

KEY WORDS: pharmacophore modeling, derivatives of five-membered heterocycles - 1,3-thiazole, 1,3,4-thiadiazole, 1,3,4-triazole, antihypertensive activity.

Адреса для листування: І. В. Драпак, Львівський національний медичний університет імені Данила Галицького, вул. Пекарська, 69 Львів, 79010, Україна, e-mail: iradrapak@ukr.net. 